\title{
Unravelling the complex nature of the Upper Weichselian till section at Gdynia Babie Doły, northern Poland
}

\author{
Piotr Paweł Woźniak ${ }^{1 *}$, Piotr Czubla² \\ ${ }^{1}$ University of Gdańsk, Department of Geomorphology and Quaternary Geology, Bażyńskiego 4, 80-952 Gdańsk, \\ Poland, e-mail: geopw@ug.edu.pl \\ ${ }^{2}$ University of Łódź, Institute of Earth Science, Narutowicza 88, 90-139 Łódź, Poland, \\ e-mail: piotr.czubla@geo.uni.lodz.pl \\ * corresponding author
}

\begin{abstract}
The complexity of glacial sequences may increase when these formed underneath ice sheets despite subsequent changes in their extent that are accompanied by alterations in the direction of the ice flow. Our aim was to determine whether or not changes in ice sheet dynamics during the Late Weichselian are also recorded in sediments formed north of the area of its fluctuating margin (i.e., where the ice sheet prevailed independent of such fluctuations). It is shown that in these areas such a record could have occurred, as documented by results of till studies at Babie Doły. The examination was carried out using several analyses: lithofacies properties of sediments, petrographic till composition (fine gravel fraction, indicator erratics), till matrix $\mathrm{CaCO}_{3}$ content, till fabric, as well as orientation of striae on the top surfaces of large clasts. In parallel, datings of sub- and supra-till sediments using the TL method were carried out. The basal till at Babie Doły represents almost the entire Upper Weichselian, but it can be divided into subunits whose features indicate different ice flow directions and debris supply. The lower subunit developed as a result of the palaeo-ice stream along the main axis of the Baltic Sea (from the north), expanding to areas adjacent to the depression of the Gulf of Gdańsk. The upper subunit developed when the influence of the palaeo-ice stream in the study area decreased, the main role having been taken over by the ice flowing from the northwest. The till analysed also shows considerable lateral variation, indicative of the mosaic nature of subglacial sedimentation. We consider the diversity of permeability of deposits over which the ice sheet extended to be the prime factor that determined such a situation.
\end{abstract}

Keywords: subglacial processes, till fabric, till petrography, Gulf of Gdańsk, Pleistocene, Fennoscandian Ice Sheet

\section{Introduction}

Complex glacial sequences rank amongst the most interesting and - at the same time - most difficult challenges for researchers of the Quaternary. The origin and nature of such sequences may manyfold, but a primary role is played by the course and conditions of glacial sedimentation. In many cases, a till section does not develop as a result of unidirectional changes in the nature of this sedimentation but rather as an expression of spatial and temporal variation of conditions at the interface of ice and bed. This leads to repetition of various till facies in the section, albeit at different vertical layouts (compare Evans et al., 2006; Piotrowski et al., 2006). The till can also show a high lateral variability, resulting from the mosaic diversity of substrate susceptibility to deformation as well as the way in which debris was deposited (Piotrowski et al., 2004).

The situation becomes even more complex when one till section contains the overlapping record of more than one ice sheet advance, as indicated by 
a clear vertical differentiation of directional characteristics and petrographic composition (e.g., Lagerlund et al., 1995; Trommelen et al., 2013; Trommelen \& Ross, 2014). This is possible in any area that was subjected to multiple ice sheet advances. The best conditions for recognising a complex till sequence are created by youngest subsurface deposits that have not been reduced as a result of subsequent erosion. In the northern hemisphere, such conditions occur in former areas of the Late Weichselian glaciation, including those located south of the Baltic Sea. At that time, the northernmost parts of Poland were in a specific palaeogeographical configuration. Throughout almost the entire period noted they remained under the ice sheet, irrespective of changes in extent, further south marked by fluctuations of the ice sheet margin (Marks, 2012; Wysota et al., 2009). The effect of this is the development of a single till bed representing glacial sedimentation throughout the Late Weichselian (Woźniak et al., 2009; Woźniak \& Czubla, 2015). This till bed can be used to study the record of changes in ice sheet dynamics, directions of debris transport and conditions of sedimentation.

In our opinion, a very good object for such research is the till bed at Gdynia Babie Doły bordering on the Gulf of Gdańsk (Fig. 1A). Research conducted there has resulted in a range of data that are relevant to the following considerations:

- identification of processes that led to the development of the till section of a complex vertical structure,

- indication of sediment characteristics which support till division into subunits,

- analysis of ice flow directions during various stages of ice sheet development in the Late Weichselian,

- correlation with results from other sites in the region in order to augment our knowledge of palaeogeographical conditions during the formation of glacial deposits in the westerly area of the Gulf of Gdańsk during the Late Weichselian. The aim of the present study was to determine whether changes in ice sheet dynamics were also recorded in sediments formed north of the area covered by fluctuations in the position of its margin (i.e., where the ice sheet prevailed independent of such fluctuations). We sought to demonstrate that in such an area this kind of record may have occurred, and that the till deposited at that time shows a complex vertical profile. We wished to tie its properties in with factors of different rank and scope of impact (temporal and spatial) and indicate which methods are best used in the study of a till section of such complexity.

\section{Regional setting}

The research site is located in the sea cliff on the eastern edge of the Oksywie Plateau (Polish: Kępa Oksywska; Fig. 1). This plateau is one of the few moraine plateau patches found in the Kashubian Coastland. Its surface gently slopes to the east and northeast. The western hummocky part reaches 70-80 $\mathrm{m}$ a.s.1. The eastern part, on the edge of which the section analysed is located, is flatter and its altitude decreases to approximately $30 \mathrm{~m}$ a.s.l. The relief of the plateau is increased by numerous erosive incisions of slopes, representing the transition to extensive depressions surrounding the plateau and separating it from the neighbouring moraine plateaus (Fig. 1B). The genesis of these depressions is debatable. They probably are inherited forms related to meltwater activity during decay of the last ice sheet, developed out of the older valley forms (compare Koutaniemi \& Rachocki, 1987; Kozarski, 1988; Rachocki \& Koutaniemi, 1992).

The substrate of the Pleistocene consists of Miocene deposits in the form of five lithological units, usually consisting of fine-grained sand, silt and clay, as well as a large proportion of lignite (Mojski, 1979). The top of the Miocene sediments extends up to $32 \mathrm{~m}$ a.s.1. (Mojski, 1979), which is why outcrops of these strata comprise a large portion of the cliff face, which is approximately $35 \mathrm{~m}$ in height (Fig. 1D). It is rather unlikely that some of them represent large glacial rafts (compare Pazdro, 1960). The sequence of Pleistocene sediments is significantly reduced, since the Miocene is directly overlain by vestigial sediments of the Warthian ice sheet, while younger beds show a patchy course and variable thickness (Mojski, 1979). Such an extensive hiatus is the result of denudation and erosion processes during the Holsteinian Interglacial, as well as exaration during the following glaciations. The best preserved are Weichselian sediments, consisting of two glacial till units representing the Middle and Upper Weichselian, respectively, separated by fluvioglacial sands and gravels and - locally - glaciolimnic sediments (Mojski, 1979; Subotowicz, 1982).

In our opinion at least part of the inter-morainic sandy sediment should be interpreted as fluvial deposits, while the older of the till units requires further study to confirm its stratigraphic position. In places where the older till unit is visible in the cliff, its course and thickness are highly variable, because of strong deformation. In some sections of the cliff the hiatus covers almost the entire Pleistocene, the Upper Weichselian till resting directly on the Miocene sediments (Fig. 1D). Until now, this till was not investigated in detail because geological studies 

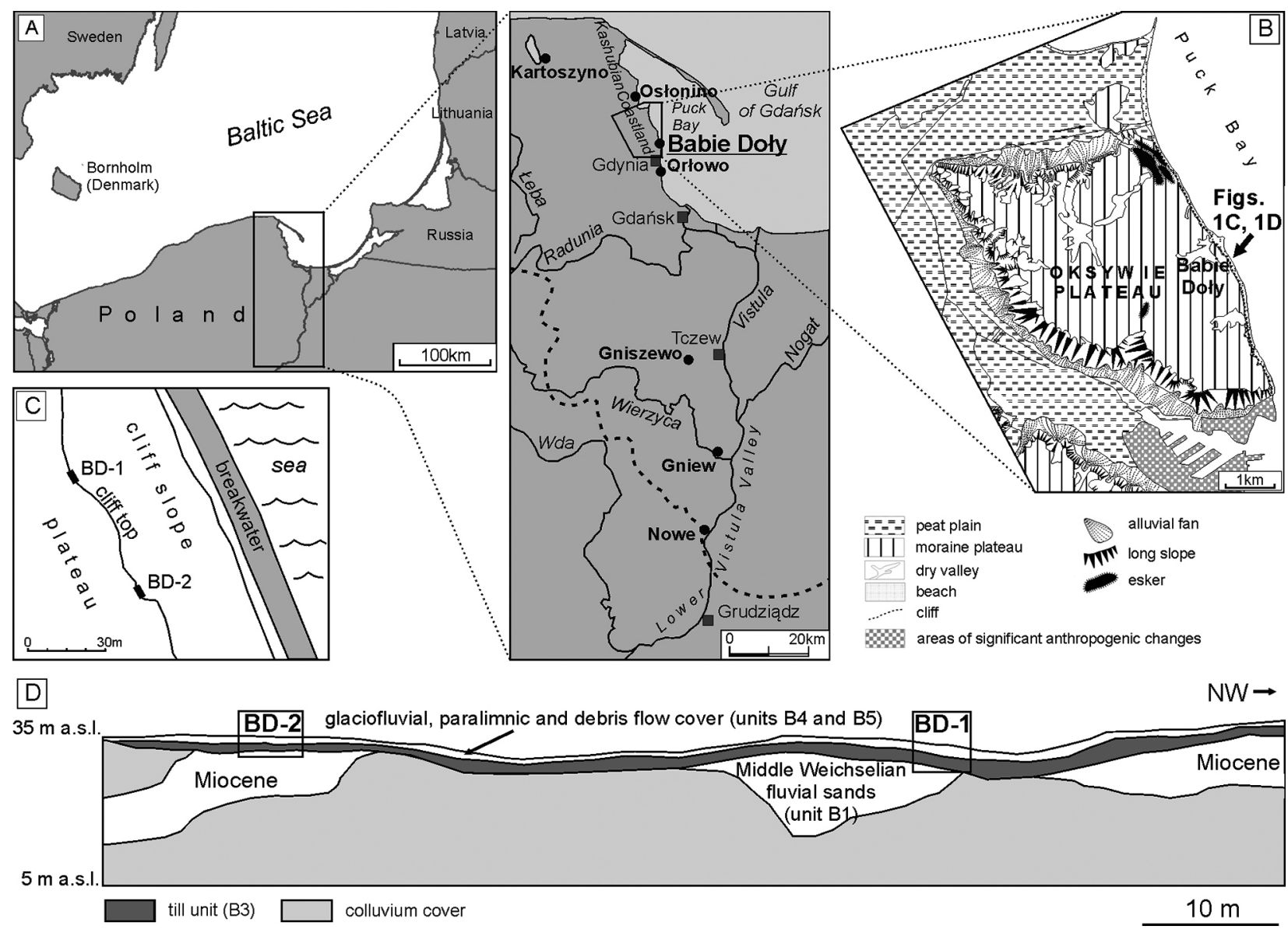

Fig. 1. A - Location of the study site and other localities discussed in the present paper; the limit of ice sheet during the Pomeranian phase, according to Marks (2012), is marked by a dashed line; B - Geomorphic sketch of the Oksywie Plateau and its vicinity (compilation based on Mojski, 1979; Pikies \& Zaleszkiewicz, 2003); C - Location of sections; D - Sketch of the part of the Babie Doły cliff analysed; due to perspective the vertical scale is changeable.

along the Oksywie Plateau were severely limited as these were military areas.

\section{Methods}

The research was carried out entirely in natural outcrops situated in two sections of the Babie Doły cliff (located c. 60 metres one from another, Fig. 1C and 1D). To start with, mapping was done at both sections, followed by determining macroscopic features and doing lithofacies analyses of sediments and sedimentary units using the lithofacies codes proposed by Miall (1978) and Eyles et al. (1983). The colour of the till was specified in accordance with the Munsell colour system. In till samples measurements of the matrix $\mathrm{CaCO}_{3}$ content were carried out following Scheibler's volumetric method/Chittick's gasometric method (see Dreimanis, 1962) for the $<0.1 \mathrm{~mm}$ fraction. Thus decalcification variability within a vertical section could be determined, and it allowed the exclusion of weathered parts of the till from petrographic analyses.

In the next phase, samples of the fine-gravel fraction $(5-10 \mathrm{~mm})$ were collected, usually from 30-cm-high intervals, but in the basal parts of glacial deposits even of $20 \mathrm{~cm}$ (Fig. 2). On the basis of petrographic analyses of samples a vertical differentiation of the till was identified. The analytic method employed was introduced in Poland by Trembaczowski (1961), with subsequent amendments by Rzechowski (1971). In each sample at least 300 gravels were identified. They were subdivided into two major petrographic groups - rocks of local provenance (Cretaceous and Cenozoic sedimentary rocks of the north Polish Lowland and adjacent areas of the southern Baltic) and Nordic (Fennoscandian and Baltic) erratics. In the latter group the following were recognised: Palaeozoic limestones $(\mathrm{Wp})$, dolomites (Dp), Proterozoic and Palaeozoic sandstones and quartzites (Pp), Palaeozoic shales $(\mathrm{Lp})$, mainly Proterozoic crystalline (igneous and 
metamorphic) rocks $(\mathrm{Kr})$ and quartz originating from disintegrated crystalline rocks (Qp). On the basis of the Nordic rocks the petrographic coefficients $\mathrm{O} / \mathrm{K}, \mathrm{K} / \mathrm{W}$ and $\mathrm{A} / \mathrm{B}$ were calculated:

$$
\begin{gathered}
\mathrm{O} / \mathrm{K}=(\mathrm{Wp}+\mathrm{Dp}+\mathrm{Pp}+\mathrm{Lp}) /(\mathrm{Kr}+\mathrm{Qp}) \\
\mathrm{K} / \mathrm{W}=(\mathrm{Kr}+\mathrm{Qp}) /(\mathrm{Wp}+\mathrm{Dp}) \\
\mathrm{A} / \mathrm{B}=(\mathrm{Wp}+\mathrm{Dp}+\mathrm{Lp}) /(\mathrm{Kr}+\mathrm{Pp}+\mathrm{Qp})
\end{gathered}
$$

Differences in lithofacies development and petrographic composition of the $5-10 \mathrm{~mm}$ fraction in the vertical section of the till bed were used to divide this into two subunits. In both subunits, directional properties of sediments were measured and analysed. For the examination of the till fabric at least 30 clasts (in each set) of considerable elongation (length ratio of pebble axes $\mathrm{a} / \mathrm{b}$ - at least $1.5 / 1$ ) with $a$-axis length between 2 and $10 \mathrm{~cm}$, were selected. The measurements were analysed with a StereoNet program and are presented here in the rose and contour diagrams. The eigenvalues and eigenvectors as well as the parameter of isotropy and elongation were calculated (Mark, 1973; Benn, 1994). The orientation of striae on the top surfaces of large clasts from the base of the till was also determined.

For our analysis of indicator erratics, clasts of a >20 mm diameter (no upper limit) were separately taken from both till subunits. Subsequently, the participation and related ratios of individual indicator erratics from different source areas in Fennoscandia and on the bottom of the contemporary Baltic Sea were established. The Theoretical Boulder Centres (TBC; Lüttig, 1958) for both subunits were calculated, and circle maps (presentation method proposed by Smed, 1993) were drawn. All calculations necessary were performed using the method proposed by Lüttig (1958), as subsequently modified by Smed (1993), Vinx et al. (1997) and Czubla (2001).

In parallel to the research described above, some datings of sub- and supra-till sediments using the TL method were carried out. Samples for age determination were collected using metal tubes $(50 \mathrm{~cm}$ in length, $5 \mathrm{~cm}$ in diameter) that were hammered into the sediment. The TL dating was performed by Stanisław Fedorowicz at the laboratory of the Department of Geomorphology and Quaternary Geology, University of Gdansk. The multiple-aliquot regenerative technique (Wintle \& Prószyńska, 1983) on quartz grains $(63-90 \mu \mathrm{m})$ was used. For a detailed description of the dating process, reference is made to Fedorowicz et al. (2013).

\section{Description and interpretation of lithofacies associations}

\subsection{Sediments below the basal till}

Sediments below the basal till show a marked lithological and age variability. Locally, they are significantly reduced and in some parts of the cliff there are Miocene sediments directly under the basal till (Fig. 1D). The latter comprise fine-grained quartz sands with a high proportion of silts and numerous interbeddings of silty and silty-clayey sediments rich in organic matter (Fig. 3A), attributable to floodplain deposition. They represent the highest elevation of Miocene sediments as delimited by Mojski (1979). In places where they appear in the cliff, they build almost its entire face. Laterally occur (Fig. 1D) Quaternary deposits in the form of an extensive sequence of sands deposited in a meandering river setting, most likely at the end of the Middle Weichselian (unit B1; see Figs. 2A and 3B). Their age is indicated by the outcome of luminescence dating (Fig. 2A). The contact between them and the Miocene sediments was not recognised, on account of an extensive colluvial cover. It can only be assumed that they fill the extensive erosive incisions in the Miocene sediments. Locally, the top of the sequence under the till analysed consists of gravelly sands a few dozen centimetres thick, which record high-pressure subglacial water flow (unit B2; see Figs. 2B and 3D).

\subsection{The basal till (unit B3)}

\subsubsection{Description}

Overall thickness of the till analysed is limited; typically from 1.4 to $1.7 \mathrm{~m}$ (Fig. 3C, D). Its contact with the substrate is sharp. At the base of the till there are single large clasts that are indicative of a possible ploughing process (Fig. 3E). In some sections of the cliff the base of the till is accompanied by a thin (up to several $\mathrm{cm}$ ) deformation zone, developed in the top of the underlying sediments (Fig. $3 \mathrm{~F})$. It contains tectonic layering, fine shear planes with accompanying small patches of detached and stretched-out small sandy bodies. Among the latter, in the bottom part of the till, occur fragments of reworked Miocene sediments.

The bottom part of the till is pale yellow (2.5Y $8 / 4)$, but the sediment becomes clearly pink above, in the section BD-1 gradually transiting from light reddish brown (2.5YR 7/4) to pink (7.5YR 7/3) in the upper part (compare Figs. 2A and $3 \mathrm{C}$ ). In section 
BD-2 the boundary between the bottom yellowish and the upper pink part is sharp (pale yellow $2.5 \mathrm{Y}$ 8/4 and pink 7.5YR 7/3, respectively; compare Figs. 2B and 3D). This difference in till colour can be linked to facies characteristics.
The lower yellowish part usually is a poorly stratified sandy diamicton (Fig. 3G). It generally contains very thin laminae (a few mm thick) of sorted sand stretching out over a few metres. The vertical space between them is varied, often more than
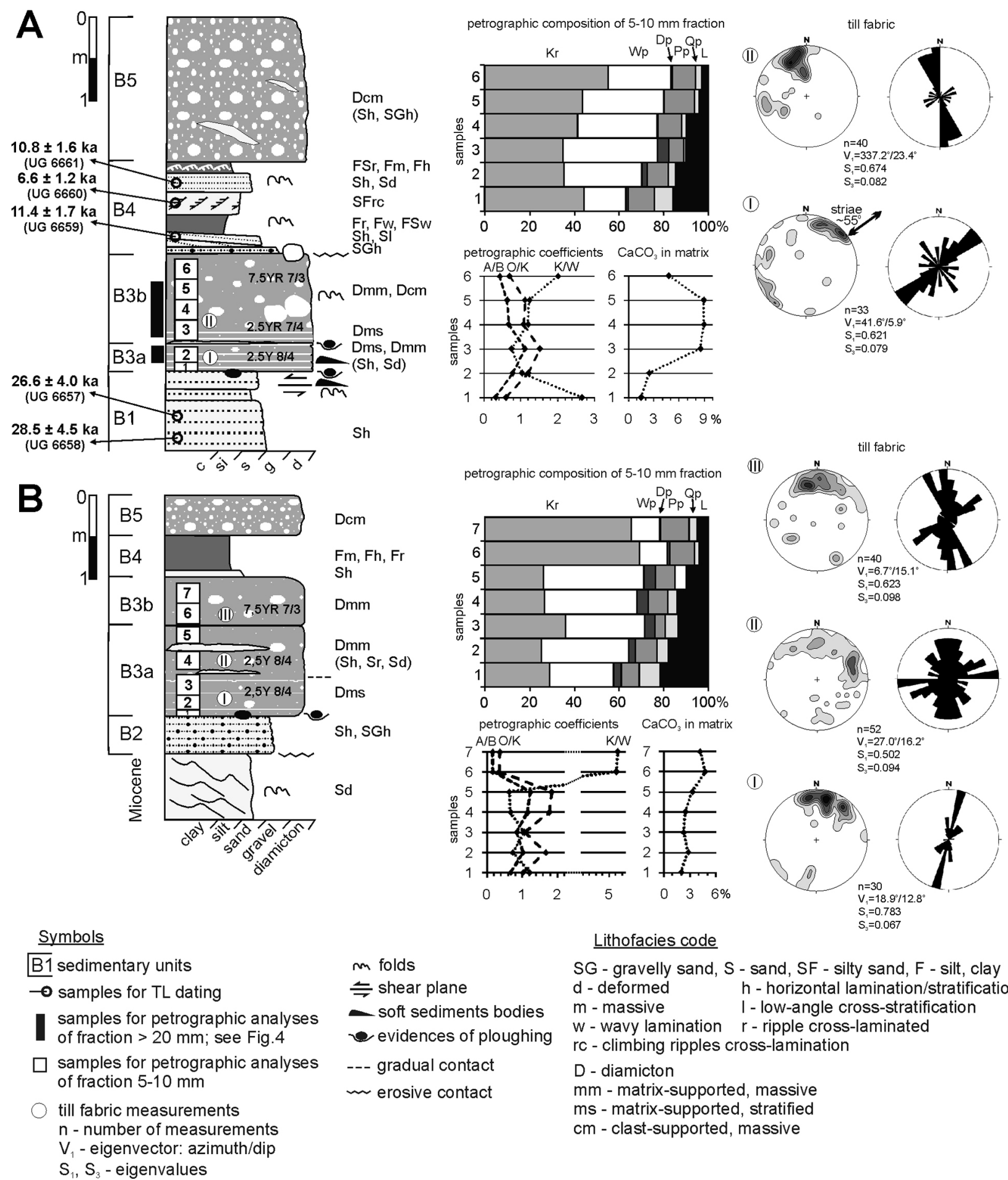

Lithofacies code

SG - gravelly sand, S - sand, SF - silty sand, F - silt, clay $\mathrm{d}$-deformed $\mathrm{h}$-horizontal lamination/stratification $\mathrm{m}$ - massive I- low-angle cross-stratification $w$ - wavy lamination $r$ - ripple cross-laminated rc - climbing ripples cross-lamination D - diamicton $\mathrm{mm}$ - matrix-supported, massive ms - matrix-supported, stratified $\mathrm{cm}$ - clast-supported, massive

Fig. 2. Logs of the sections studied and results of selected analyses. A - BD-1; B - BD-2; lithofacies code is based on Miall (1978) and Eyles et al. (1983); symbols of petrographic groups and coefficients - for explanations, see text. 
$10 \mathrm{~cm}$. In some sections of the cliff the diamicton of these characteristics is replaced by a massive diamicton. Locally, at the bottom of a yellowish diamicton there are large irregular sandy bodies, although with a flat bottom contour (Fig. $3 \mathrm{H}$ ). They are deformed and in places enriched in diamicton material. In section BD-2, where the yellowish diamicton has a much greater thickness than in BD-1, its top part contains a few-cm-thick sandy intercalations (Fig. 3I). In addition to the horizontal lamination they include recognisable current ripples. The primary sedimentary structures in these intercalations often are deformed.

The transition from the lower yellowish diamicton to the pink one, which forms the highest part of the bed, has a different character. A gradual transition, with alternating thin layers (1-3 cm thick) of yellowish and pink diamictons is observed in section BD-1 (Fig. 3J). Here the lower, the yellowish part, over a considerable distance, accounts for only approximately one-third to one quarter of the bed as well. As noted earlier, in the second section (BD2) the boundary between the till subunits is sharp. The relationships between thickness of colour variations are also different there: the yellowish diamicton predominates (it reaches approximately 1-1.2 $\mathrm{m})$, while the pink one, comprising the top part, has a thickness of no more than $50 \mathrm{~cm}$, locally decreasing to only $30 \mathrm{~cm}$.

The variable thickness of the pink diamicton is also reflected in the fact that in the sections presented here it differs in structural characteristics (compare Figs. 2A, 2B, 3C, 3D). In section BD-1, where the pink diamicton has a relatively large thickness, it is layered in the basal part (Fig. 3J). Above, its structure grades into to a massive one, wherein locally in this part of the section there is a zone enriched in gravels and boulders and containing small sandy intercalations. It also includes strongly deformed, S-shaped sandy laminae (Fig. 3K). At the top of the bed there are isolated boulders that protrude above the diamicton. In section BD-2, wherein the pink diamicton has a small thickness, there are no such features; the diamicton has a totally massive structure (Fig. 3L).

It is also worth noting that both in section BD-2 and at the cliff section between BD-1 and BD-2 at the bottom of the pink diamicton there are clasts, whose lower parts are in the topmost part of the yellowish diamicton (Fig. 3M). In cases where they are clearly elongated, their orientation is W-E or WNW-ENE. The dip angles of the long axis of such clasts are small, typically a few degrees. Clear polishing of the upper surface, pointing up-glacier (oriented in a westerly or west-north-westerly direction), is seen in only some of them.

\subsubsection{Interpretation}

Features of the deformation zone that is developed in the upper part of the deposits underlying the till are related to the dynamic effects of the ice sheet on the substrate under conditions of a warm thermal regime. The bottom part of the till shows a melt-out and decoupling character (Fig. 3G; compare Piotrowski \& Tulaczyk, 1999; Piotrowski et al., 2006; Wysota, 2007), developed during the motion of the ice sheet. It documents multiple changes in subglacial water pressure. At the time of its increase up to values balancing the pressure exerted by the ice cover, ice-bed decoupling occurred (Piotrowski \& Tulaczyk, 1999) leading to acceleration of the basal slip, followed by a subglacial water flow responsible for the formation of thin laminae of sorted sand (e.g., Alley, 1989; Jørgensen \& Piotrowski, 2003; Piotrowski et al., 2006). The draining-out of water from the ice sheet sole (subglacial water pressure drop) resulted - again - in debris lodging during recoupling of the ice to the bed.

Distances in the decoupling record of the vertical section - usually c. $15-20 \mathrm{~cm}$ - show that the process described was repeated many times (as indicated by a large number of sandy laminae), but probably at long intervals (quite long periods of deposit accretion from glacial traction). This assumption stems from the fact that if the till, which represents here an entire stadial, is not thick (c. 1.5-1.7 $\mathrm{m}$ ), the accretion rate was also low (in relation to the length of time during which this till was laid down). The presence of large, irregular sandy bodies of flat-bottom shape and deformed upper surface, recorded in the lower part of the till (Fig. 3H), may indicate depositional episodes in small subglacial channels (compare Piotrowski et al., 2009), the filling of which was subsequently deformed once the hydrogeological conditions changed (compare Piotrowski et al., 2004; Tylmann

Fig. 3. (right) Selected features of the facies analysed at Babie Doły; locations of places presented in the photographs are marked on the sketch in the top of the figure; arrows indicate ice flow direction. A - Deposits under the complex glacial sequence: Miocene flood plain deposits; B - Deposits under the complex glacial sequence: unit B1 - fluvial sands of Middle Weichselian age, deposited by a meandering river; C - Section BD-1: general overview; D - Section BD-2: general overview; E - One of the signs of ploughing; F - Thin deformation zone under the basal till; note the detached and stretched-out sandy bodies. 

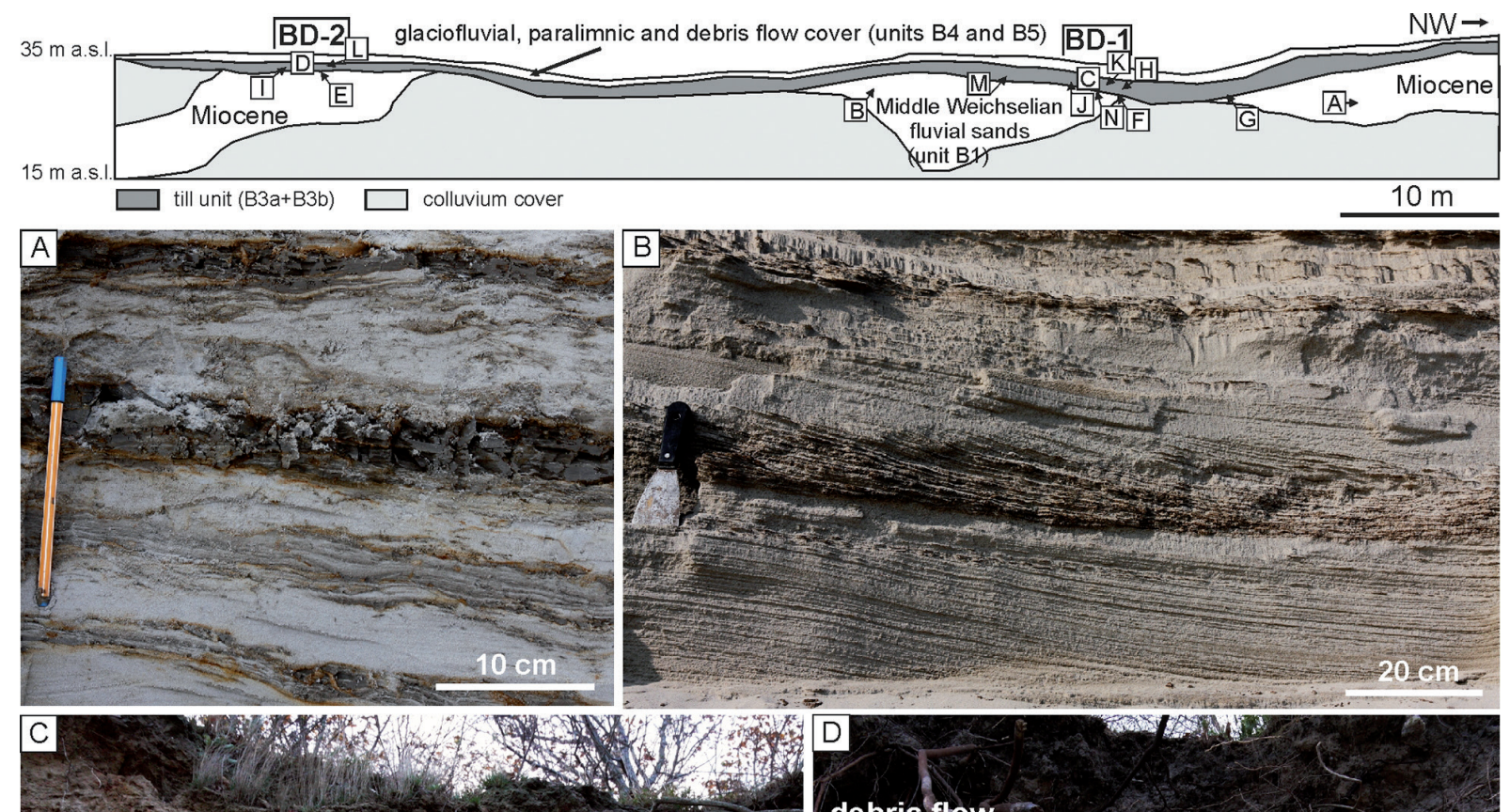

\section{debris flow \\ deposits (unit B5)}

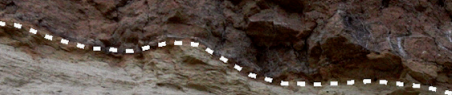
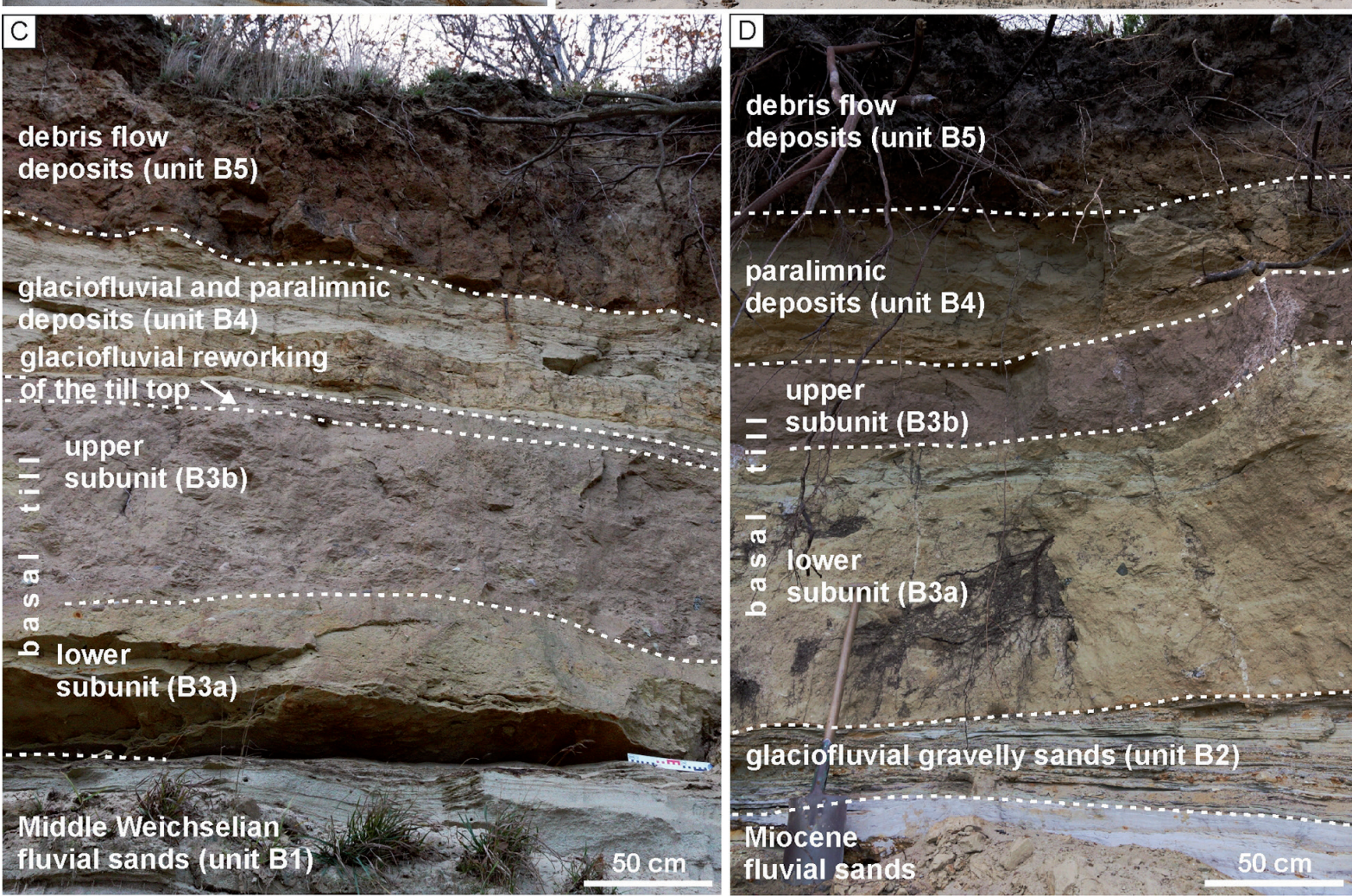

debris flow

deposits (unit B5)

olaciofluvial and paralimnic deposits (unit B4)
glaciofluvial reworking

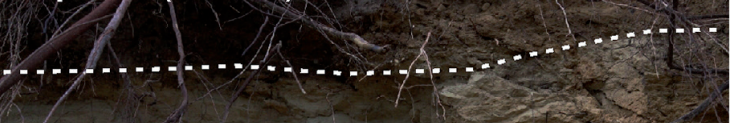

paralimnic

deposits (unit B4)
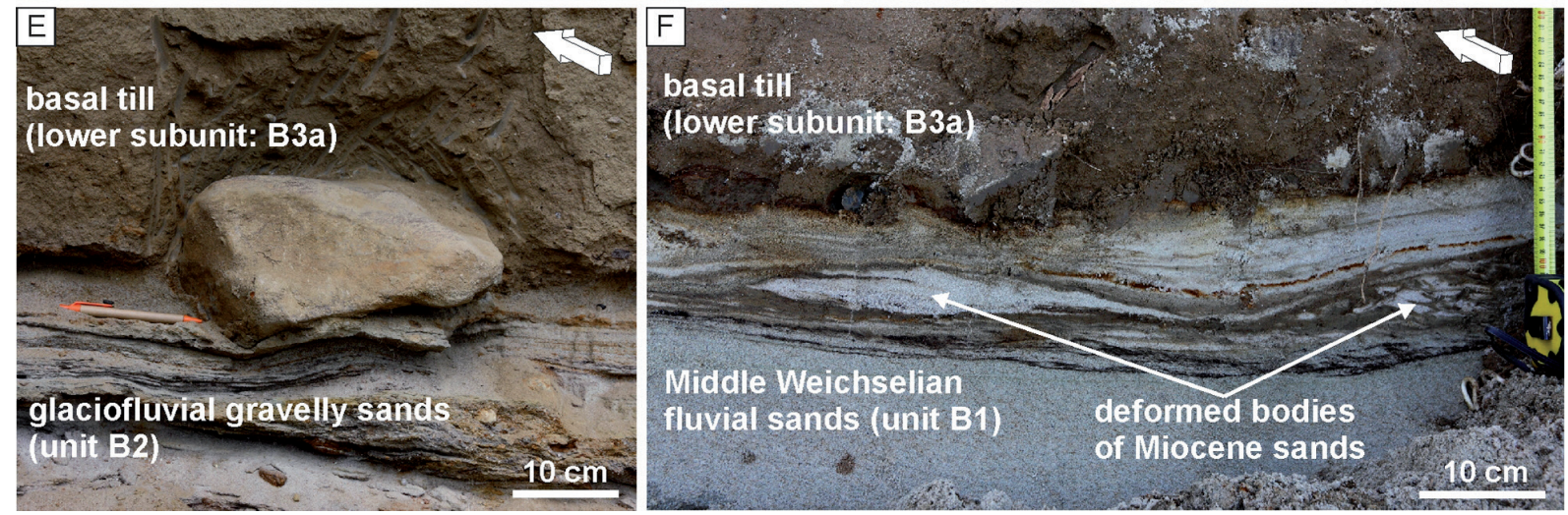

\section{upper}

$=$ subunit (B3b)

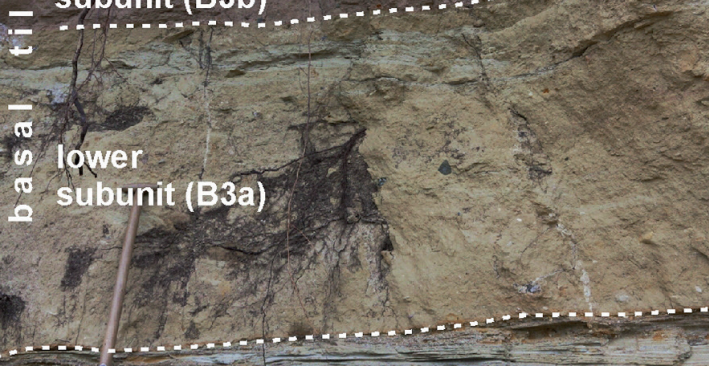

glaciofluvial gravelly sands (unit B2)

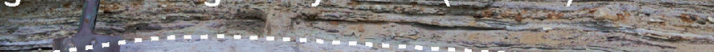

Miocene

luvial sands 2

basal till:

(lower subunith B3a)

Middle Weichselian

fluvial sands (unit B1)

deformed bodies

of Miocene sands 

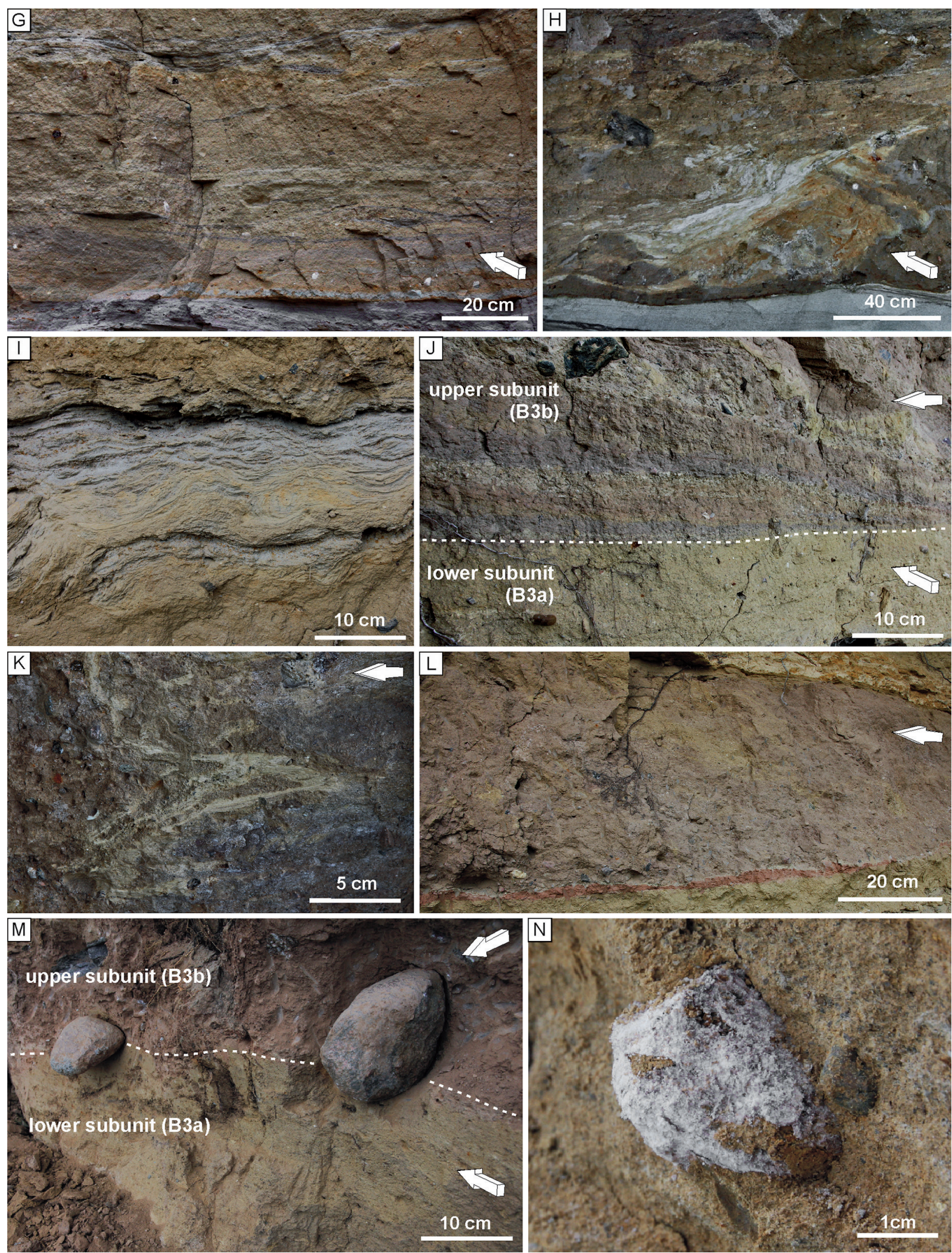

Fig. 3. cont. G - Evidence of ice-bed decoupling in subunit B3a; H - Deformed sandy body (former infilling of a subglacial channel) in subunit B3a; I - Deformed sandy intercalations in the top part of subunit B3a; J - Stratified nature of the basal part of subunit B3b in section BD-1; K - Deformed S-shaped sandy laminae in the upper subunit of the basal till (B3b); L - Homogeneous structure of the upper subunit of the basal till (B3b); $\mathbf{M}$ - Contact between the basal till subunits: ploughed pebbles; $\mathbf{N}$ - Partly etched surface of a clast of Palaeozoic limestone in the weathered basal part of subunit B3a. 
et al., 2013). The gravelly sands that occurred in section BD-2 under the analysed till (Figs. 2B, 3D) also record the high-pressure subglacial water flow.

Where the thickness of the yellowish till (subunit B3a) is greater (section BD-2) the upper part of the section can be delimited, indicating an important phase of ice sheet stagnation, where the passively melting-out debris locally underwent processing by subglacial flow of the water discharged from the bottom of the melting ice (Fig. 3I; compare Shaw, 1982). The resulting glaciofluvial sandy intercalations are deformed, which may be attributed to the post-depositional gravity motion of the sediment during both subglacial melting-out (Evans et al., 2006) and subsequent impact of the active ice (see below).

Sedimentation resumed during the ice motion is visible in the upper part of the section in the form of a pink diamicton (subunit B3b). This is evidenced by smudges of yellowish diamicton in the bottom part of the pink diamicton (Fig. 3J) as well as clasts, whose bottom parts protrude from the pink diamicton and are stuck in the topmost part of the yellowish diamicton (i.e., indicative of a ploughing process; Fig. 3M; compare Clark \& Hansel, 1989; Evans et al., 2006; Piotrowski et al., 2006). The massive structure of the pink diamicton (subunit B3b) in section BD-2 (Fig. 3L) indicates the stable nature of sedimentation. The melted-out diamicton was probably subjected to intense shearing, leading to sediment homogenisation (compare Evans et al., 2006; Piotrowski et al., 2006; Salamon, 2014). It should be noted that the lack of evidence of ice-bed decoupling may be due to the fact that their record was destroyed as a result of shearing (compare Evans et al., 2006). The stress transmission downwards could also have been responsible for the deformation of the sandy intercalations in the upper part of the previously deposited yellow diamicton (Fig. 3I).

The reasons behind the variable thickness of both diamictons, described in the previous section, may be different. It could have been glacial erosion associated with reactivation of the ice sheet and incorporation of the top part of the lower diamicton (subunit B3a) into the base of the upper one (subunit B3b). Hence, for example, there are smudges of yellowish diamicton in the basal part of the pink one. This may explain the differences in thickness of subunit 3a. On the other hand, boulders protruding from the top of the till indicate that in the northern parts of the cliff analysed (BD-1 and vicinity) the thickness of the till unit described is slightly reduced. In the light of what thickness the till reach- es in different sections of the Oksywie Plateau cliff (no more than $2 \mathrm{~m}$ ), and which parts of its section are preserved, it can be estimated that no more than about 20-30 cm were removed from the top part in section BD-1.

\subsection{Sediments above the basal till (units B4 and B5)}

\subsubsection{Description}

The basal till is covered by a sediment complex visible over a considerable length in the Babie Doły cliff (Fig. 1D). This part of the sequence shows a diverse thickness (the largest of about $2 \mathrm{~m}$ ). Typically, the smaller the thickness, the lesser the lithofacies diversity of the sediments (compare thicknesses of units B4 and B5 in Figs. 2A and 2B). The contact with the glacial till is often erosive, as evidenced by boulders protruding from the top of the till in section BD-1 and the associated sandy-gravel and coarsegrained sand lithofacies (Figs. 2A, 3C). Above the till and sand contact are two lithofacies sets which indicate more dynamic flows (medium-grained sand, lithofacies Sh) and quieter suspended load deposition, probably in a small flow-through basin (silt and silty-sandy facies). Although the obtained TL age of these deposits (unit B4) should be regarded as an underestimate (Fig. 2A), the dating indicates their appearance at the end of the glacial period. The sequence is topped with a massive clast-supported diamicton (unit B5). In some places, this contains small lenses of other deposits, usually sandy, indicating diamicton reworking by meltwaters.

\subsubsection{Interpretation}

The sediments directly above the basal till (units B4 and B5; see Figs. 2A, 2B, 3C, 3D) can be ascribed to a sheet flood of glaciofluvial water. In the first stage, when the flow was still passing over the till surface, its topmost part was eroded. What is observed above is the record of blockage of water flow and transition to quieter paralimnic sedimentation (compare Brodzikowski \& van Loon, 1991). Probably, the genesis of the topmost part of the Babie Doły section (unit B5: clast-supported diamicton) can be attributed to gravity flows (mostly cohesive ones) of the debris melted out from dead ice blocks (compare Boulton, 1977; Bennett \& Glasser, 2009). Although no direct evidence of dead ice blocks was encountered in the Babie Doły cliff, it should be emphasised that the diamicton cover indicates the proximity of the source of such material. 


\section{Petrographic composition of the till}

\subsection{Introduction - a question of till weathering at Babie Doły cliff}

Pomerania is the region where significant till weathering, which modifies its original petrographic composition, is often observed (Woźniak, 2006). At Babie Doły, in addition to signs of weathering processes involving different sections of the top part of the profile of the analysed till, a much rarer phenomenon is observed, i.e., partial decalcification of its basal part. It includes the first several centimetres, which is confirmed by determination of the $\mathrm{CaCO}_{3}$ content in the $<0.1 \mathrm{~mm}$ fraction (Fig. 2). The result of this phenomenon is a significant reduction in the participation of carbonate rocks. The remaining clasts have a highly etched surface (Fig. 3N). Not only was leaching of carbonates noted, but also disintegration of crystalline rocks rich in mafic minerals (mainly biotite), less resistant to weathering, into monomineral grains. This resulted in values of the petrographic coefficients: the $\mathrm{O} / \mathrm{K}$ and $\mathrm{A} / \mathrm{B}$ values are very low, while $\mathrm{K} / \mathrm{W}$ - high (for details, see below). In the upper part of the section the $\mathrm{CaCO}_{3}$ content in the matrix increases rapidly, and the effects of decalcification are negligible, which is confirmed by values of petrographic coefficients. The reasons for partial decalcification of the basal part of the till are presented below (section 7).

\subsection{Petrographic composition of the fine gravel fraction $(5-10 \mathrm{~mm})$}

The complexity of the basal till at Babie Doły manifests itself not only in the variation of its macroscopic characteristics, but also in results of petrographic composition of the $5-10 \mathrm{~mm}$ fraction (Fig. 2). Along with diverse characteristics of lithofacies properties, they were the basis for the subdivision of the till into two subunits (B3a and B3b; see Fig. 2). In section BD-1 the bottom subunit extends to approximately $40 \mathrm{~cm}$ from the base and is predominated by sedimentary rocks of far transport over the crystalline rocks (taking into account that the petrographic composition of the basal part was significantly influenced by weathering processes), as well as a high content of rocks of local provenance (approximately 15\%).

What is also important is the presence of dolomites, which are almost absent in the upper subunit. Only in the basal part of the pink diamicton, in places where the incorporation of the yellow diamicton is observed, is its composition inherited from the lower diamicton (Palaeozoic limestones predominate over crystalline rocks; presence of dolomite). In the upper subunit (pink diamicton) the percentage of rocks of local provenance significantly decreases. Moreover, the proportions of the main groups of far-transported (i.e. long-ranged) rocks also change in favour of crystalline rocks; this is expressed, among others, by changes in the values of the petrographic coefficients: decrease in $\mathrm{O} / \mathrm{K}$ and $\mathrm{A} / \mathrm{B}$ and increase in $\mathrm{K} / \mathrm{W}$ (Fig. 2A).

Trends in section BD-2 are similar and are also associated with a change of till colour (Fig. 2B). The entire yellow diamicton shows a very large proportion of Palaeozoic limestones and a fairly large amount of dolomites amongst long-ranged rocks (which means a high value of the coefficient $\mathrm{O} / \mathrm{K}$ and low of $\mathrm{K} / \mathrm{W}$ ) as well as a significant proportion of rocks of local provenance. Only in the two uppermost samples collected, i.e., in the pink diamicton (subunit B3b), does the participation of rocks of local provenance significantly drop (down to approximately $4-5 \%$ ), and proportions in long-ranged rocks change. In the case of the latter, there is a shift towards a clear predominance of crystalline over sedimentary rocks, including carbonates. It is so significant that it might be assumed to be the result of decalcification of the top part of the till unit. However, this is contradicted by results of analyses of matrix $\mathrm{CaCO}_{3}$ content, as this is the top part which contains most of it (compare Fig. 2A). The results for the samples from sections further down by $2.5-3 \%$ might suggest that the most decalcified part of the section is the one which was sampled, but results of petrographic analysis of the fraction 5-10 $\mathrm{mm}$ (very high content of Palaeozoic limestones, largely of dolomites) contradict this (see Fig. 2B). In line with this is also the content of quartz, which should have increased in the case of till weathering (which is confirmed by results for samples collected in the two sections of weathered basal parts which contain significantly more quartz). In the top part of the till studied such a phenomenon was not observed; similarly, there was no evidence of intense weathering processes on the surface of the grains of the $5-10 \mathrm{~mm}$ fraction studied.

\subsection{Petrographic composition of $>20 \mathrm{~mm}$ fraction}

Studies of indicator erratics of the $>20 \mathrm{~mm}$ fraction were carried out independently for the two diamicton subunits (B3a and B3b), delimited on the basis of petrographic analyses of the fine gravel fraction and lithofacies variability. These very la- 
bour-intensive analyses proved possible only in the first of the sections analysed, i.e., BD-1. The small thickness of the upper till subunit in section BD-2 and the limited horizontal size of the outcrop made it impossible to collect a representative erratic sample (minimum 1,000 clasts). Acquiring such a large sample requires sorting loads of cubic metres of glacial deposits. The small distance between the sections, however, allows extrapolation of data from section BD-1 onto both sections at Babie Doły.

The petrographic differentiation of the $>20 \mathrm{~mm}$ fraction is reflected an upward decrease of the par-

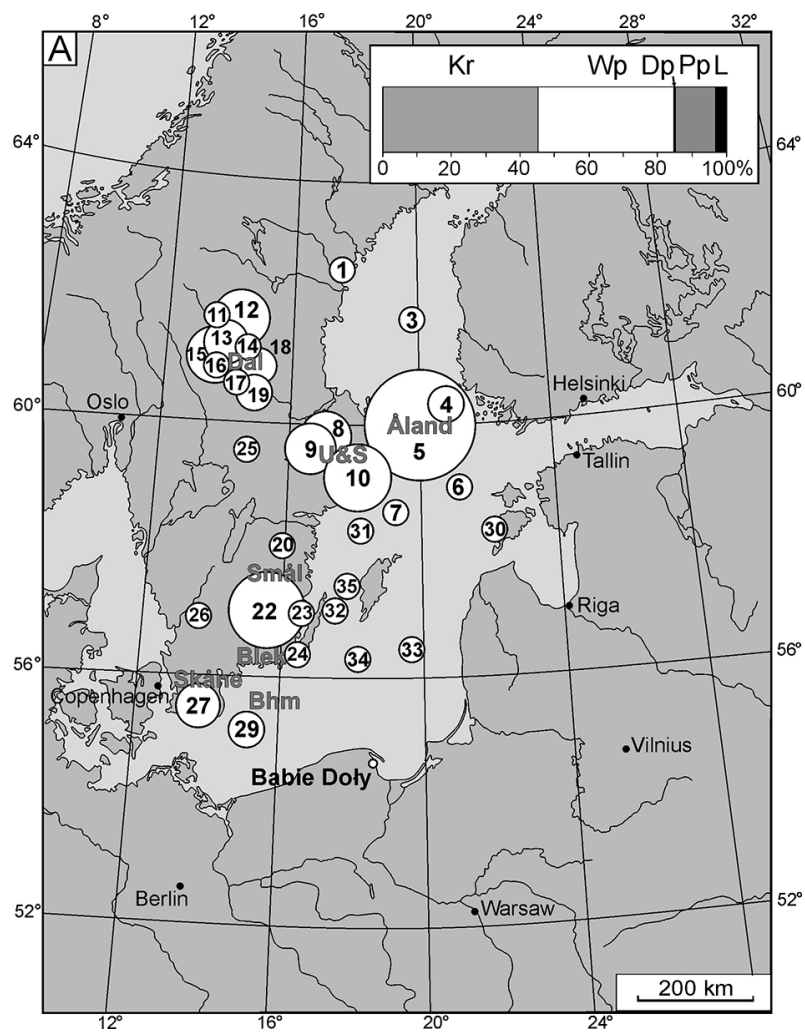

ticipation of erratics of local provenance. In the lower subunit it is around $4 \%$, while in the upper one there are no erratics of local rocks at all. These percentages for rocks of local provenance are several times lower than those observed in the finer fraction of the same subunits (compare Figs. 2A, 2B with Figs. 4A, 4B).

What is also different is the composition of the Baltic-Fennoscandian rocks in both subunits (compare insets in Figs. 4A, 4B). In the lower subunit, limestones constitute $39.5 \%$ and dolomite $0.2 \%$ of the long-ranged rocks, while in the upper subunit

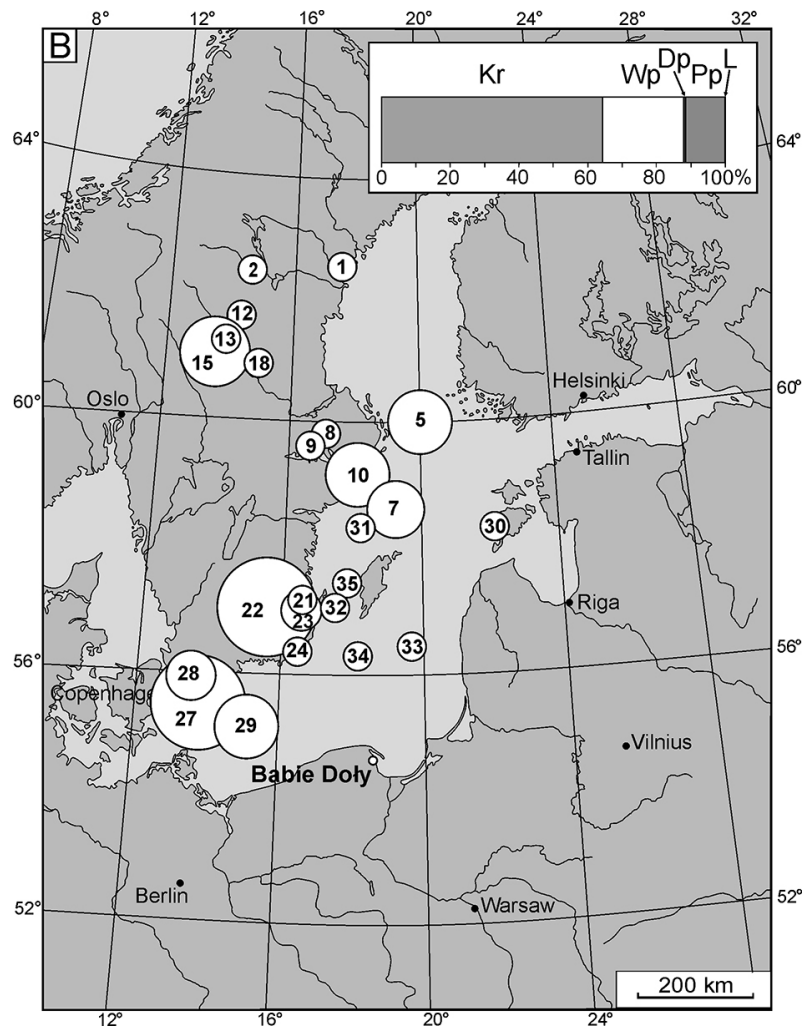

Fig. 4. Petrographic composition of the $>20 \mathrm{~mm}$ fraction in the till analysed. A - lower subunit (B3a); B - upper subunit (B3b); maps - indicator erratics (Woźniak \& Czubla, 2015, in part modified); insets - percentages of main petrographic groups (symbols - see explanation in text); sampling sites - see Fig. 2A; source areas of indicator erratics mentioned in text (bold grey letters): Åland - Åland region, Bhm - Bornholm, Blek - Blekinge, Dal - Dalarna, Skåne - Skåne, Smål - Småland, U\&S - Uppland and Stockholm region; the circle area corresponds with the percentage of erratics in the stone sample analysed; numbers in maps: 1 - Rödö granite and granite porphyry, Rödö quartz porphyry, 2 - Rätan granite, 3 - Bothnian porphyries, 4 - Åland and/or Nystad pyterlite, 5 - Aland granite, Haga granite, Åland rapakivi, Åland aplite granite, Åland granite porphyry, 6 - red Baltic quartz porphyry, 7 - brown Baltic quartz porphyry, 8 - Uppsala, Vänge and Arnö granites, 9 - Sala granite, 10 - Stockholm granite, 11 - Särna porphyry and tinguaite, 12 - Grönklitt and grey Dalarna porphyries, Åsby diabase, 13 - Åsen, Bredvad and Kåtilla porphyries, Garberg granite, 14 - Blyberg porphyry, Klittberg ignimbrite and porphyry, Rännas, Blyberg, Orrlok and other Dalarna ignimbrites and porphyries, 15 - Öje diabase and melaphyre, Dala sandstone, Digerberg sandstone and conglomerate, 16 - Heden porphyry, 17 - Venjan porphyry, 18 - Järna granite, 19 - Siljan granite, Siljan rapakivi, Mänsta porphyry, 20 - Kinda granite, 21 - Flivik and Virbo granites, Påskallavik and Sjögelö porphyries, 22 - red Småland granites, Vislanda granite, Småland porphyries, 23 - Vånevik granite, 24 - Kalmarsund and Tessini sandstones, 25 - Kristinehamn granite, Filipstad granite (southern variant), 26 - garnet amphibolite, 27 - Skolithos and Hardeberga sandstones, 28 - Skåne basalt, 29 - Hammer and Vang granites, Bornholm gneisses, 30 - dolomites, 31 - red Cambrian sandstones, 32 - red Ordovician limestones, 33 - Old-Red sandstone, 34 - Beyrichia limestone, 35 - Palaeoporella limestone. 
$23.4 \%$ and $0.5 \%$ respectively. The proportion of crystalline rocks (igneous and metamorphic) changes in both till subunits exactly in the reverse direction. In the bottom subunit it is $45.2 \%$, while in the upper it rises to $64.4 \%$. This difference is reflected mainly in the twice as high content of metamorphic rocks in the upper part of the profile: $23.8 \%$ compared to $11.7 \%$ in the lower one. A similar differential share of igneous rocks is significantly lower: $40.7 \%$ in the upper subunit and $33.5 \%$ in the lower one. The participation of sandstones throughout the entire basal till section is at a relatively stable level: about $12 \%$ in the lower subunit and $11 \%$ in the upper subunit. The variation in petrographic composition of the $>20 \mathrm{~mm}$ fraction in both subunits is very similar to that observed previously in the $5-10 \mathrm{~mm}$ fraction. Another feature is the complete lack of rocks of local provenance in the coarser fraction in the upper subunit and the negligible content of dolomite in both subunits distinguished.

The identified indicator erratics represent $>15 \%$ of specimens of the Baltic-Fennoscandian crystalline rocks in the lower subunit, and only $6.0 \%$ in the top one. An unusually high proportion of indicator erratics identified in the sample from the lower subunit could have been influenced by a significant

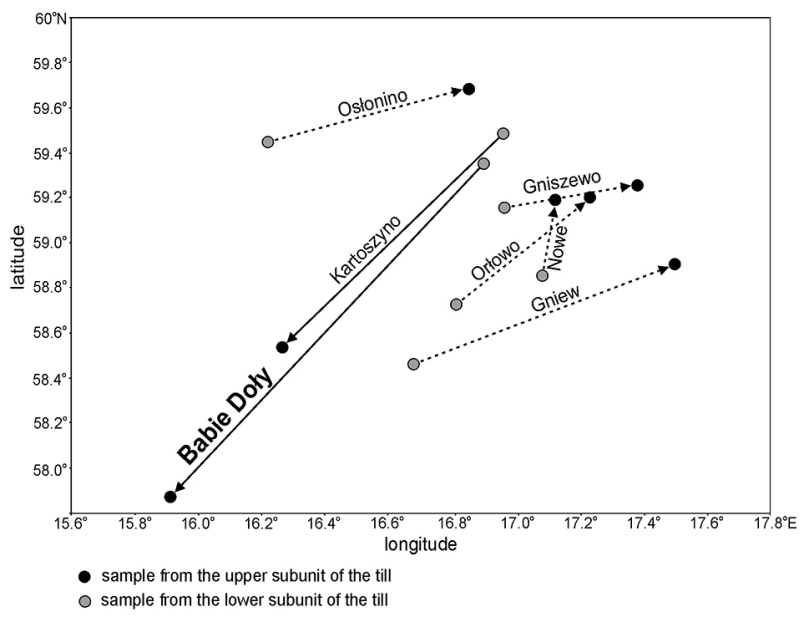

Fig. 5. Vertical petrographic differentiation of the till analysed, compared to results obtained for the Upper Weichselian till at other sites (location: see Fig. 1) Theoretical Boulder Centres (TBC) of samples of the $>20 \mathrm{~mm}$ fraction; to obtain an image that is consistent with results of previous studies (inclusive of Woźniak et al., 2009; Woźniak \& Czubla, 2015), the co-ordinates of the TBC shown in the figure were based on indicator erratics and the expanded group of auxiliary erratics, including certain types of calcareous rocks (see Czubla, 2001); different styles of arrows indicate various shift directions of the TBC location of the upper subunit of the till in relation to the one calculated for the lower subunit. representation of easily recognisable Åland erratics (Nos. 4 and 5 in Fig. 4A). They account for as much as $31 \%$ of all indicator erratics recognised. Somewhat less important in the lower part of the till unit are the Dalarna erratics (Nos. 11-19) as well as erratics from Uppland and the Stockholm area (Nos. 8-10): $21.1 \%$ each. The erratics of southeast Sweden (Blekinge and Småland - Nos. 20-24) constitute only $15.5 \%$ of the analysed group, while the proportion of Bornholm rocks (No. 29) is minimal: 2.8\%.

Proportions between groups of crystalline indicator rocks in the composition of the upper till subunit in Babie Doły are arranged quite differently (Fig. 4B). The rocks that predominate among them are those from Småland and Blekinge (Nos. 21-24); they constitute $34.1 \%$ of the total. More than twice less numerous are erratics from areas of the central coast of Sweden (Uppsala and Stockholm area, Nos. 8-10); they account for $15.9 \%$ of the sample studied. The percentage of Åland rocks (No. 5) is extremely low in relation to the values common in the Pomeranian tills (compare Woźniak \& Czubla, 2015) $-13.6 \%$, while the Dalarna rocks are represented by a few erratics in the sample. The radical change in the supply area of the ice sheet into the southwest (in relation to the lower subunit) was confirmed by a large representation of Bornholm rocks (No. 29 in Fig. $4 \mathrm{~B}$ ) - as much as $11.4 \%$ of the analysed sample - and a fairly large number of Skåne erratics (6.8\%). The correctness of these conclusions is further emphasised by a very large percentage of Hardeberga sandstone (No. 27). The proportions of indicator erratics from different parts of Fennoscandia determine the location of the TBC (Fig. 5). This ratio calculated for crystalline rocks, supplemented by the typical sandstones, confirms a shift in the debris source area from the northeast to the southwest.

\section{Till fabric}

In our analysis of directional properties of the clast fabric, measurements were conducted in both sections, separately for each of the subunits. All the measured sets (with exception of series II of section BD-2) show a moderate to strong concentration of the $a$-axis azimuth of clasts around the dominant direction (Fig. 2). It is indicated not only by the image obtained in both types of charts, but also high eigenvalues $S_{1}$ of well above 0.6 , as well as a low isotropy and significant elongation (Fig. 6). The a-axis azimuths are particularly concentrated in the lower part of the bottom subunit of section BD-2 ( $\mathrm{S}_{1}$ $=0.783)$. In this series there is also a shear system accompanying the dominant sector. The orientation 
of some clasts in some sets (in set I in section BD-1 and in all sets in BD-2) is oblique to the dominant sector.

Measurements in subunits B3a and B3b clearly indicate different ice flow direction. The dominant sectors in the diagrams and azimuth of the eigenvector $\mathrm{V}_{1}$ for the measurements sets obtained in the lower subunit (B3a) in both sites indicate an ice flow from the NNE-ENE sector. Since the occurrence of ploughed large clasts in the bottom of the basal till was confirmed, they were tested for the presence of striae. Distinct striae which were found on one of such clasts in section BD-1, along with a clear up-glacier side of the clast with the polished top surface, also meaning ice flow from the ENE. The results of the research of till fabric in subunit B3b document a marked change in the dominant sector into the NNW.

The inconsistent distributions of the clast fabric in some sets (in set I in section BD-1 and in sets II and III in BD-2) mentioned above, can be associated with a change from parallel to transverse clast rotation in relation to the ice motion (compare Carr \& Rose, 2003). In contrast, a highly aligned till fabric (Fig. 6) suggests the formation of the given bed section during the motion of the ice (compare Benn, 1994; Larsen \& Piotrowski, 2003; Hart et al., 2009). This is consistent with conclusions based on the macroscopic characteristics of the various parts of the till section analysed. This is extremely important because clast fabric alone should not decide about the genetic till type (compare Bennett et al., 1999; Evans et al., 2006). A very large spread of clast orientation and the girdle fabric shape (effect of

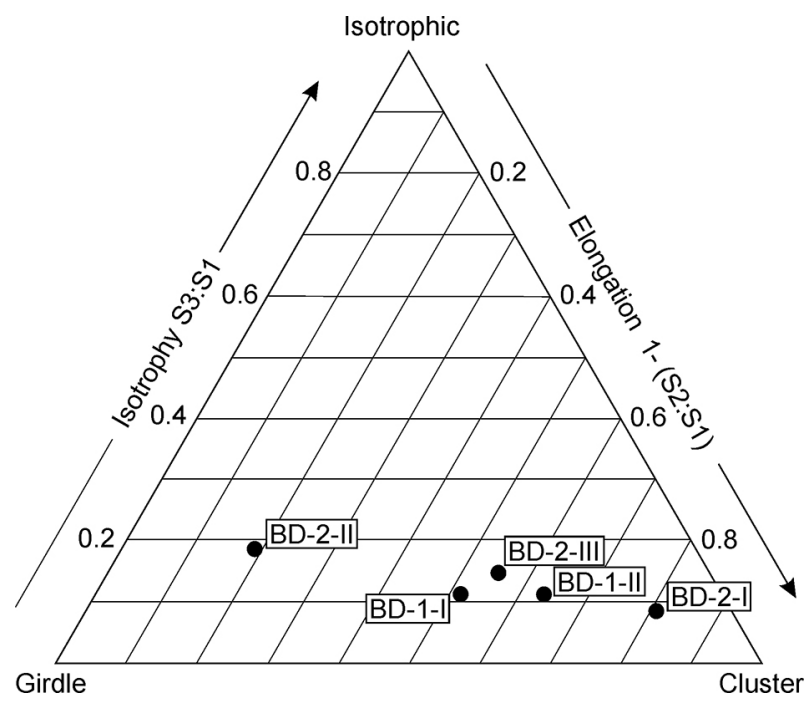

Fig. 6. Till fabric at Babie Doły: general shape triangle; sampling sites - see Fig. 2A and 2B; the method proposed by Benn (1994) is applied. clast reorientation) in set II in section BD-2 (Figs. 2B and 5) can be of a complex origin: the impact of the shear stress transmitted from the sole of active ice (which deposited the upper subunit) into its substrate might have been imposed on effects of the melt-out processes (stagnant ice sheet).

\section{Discussion}

Analyses of till sections along a cliff stretch of approximately $80 \mathrm{~m}$ revealed a significant lithofacies variability. Even in short sections of several metres in the lower subunit (yellowish till) there is a transition from stratified diamicton with record of numerous decoupling events to massive diamicton or diamicton poor in laminae. This indicates a large spatial variation of rheological conditions in the ice sheet sole, conditioning the formation of the ice-bed decoupling and short-term subglacial flows leading to the deposition of thin sandy laminae (compare Piotrowski \& Tulaczyk, 1999; Jørgensen \& Piotrowski, 2003; Piotrowski et al., 2006). Occasionally, the formation of subglacial channels occurred allowing deposition of the sorted sediments of a larger thickness (compare Piotrowski et al., 2009). Some of them were subsequently deformed when ice-bed coupling was restored (Fig. $3 \mathrm{H}$ ). These characteristics indicate that the subglacial till described here developed as a result of changing conditions of sedimentation as well as a combination of deposition and deformation, i.e., subglacial traction till (sensu Evans et al., 2006).

The development of ice-bed decoupling was induced by subglacial water pressure, i.e., its increase up to values balancing the pressure exerted by the ice sheet cover (Paterson, 1994). The subglacial water pressure increase was favoured by limited infiltration into the substrate, while its decrease - by a more permeable substrate. Along with the change in deposits along which the ice sheet moved, the lithofacies characteristics of deposits formed might have changed (compare Alley, 1989; Piotrowski et al., 2006; Salamon, 2014). In the cliff at Babie Doły the till analysed is underlain by various deposits positioned side by side but showing different permeability. The fine-grained Miocene sediments with interbeddings enriched in organic matter are laterally adjacent to the Pleistocene sands with better permeability (Figs. 1D, 3A, 3B). Such an arrangement favoured the diversity in water pressure in the bed, and thus also the variability of sedimentation conditions and heterogeneous susceptibility of sediments to deformation (compare Piotrowski \& Kraus, 1997; Piotrowski et al., 2004, 2009). 
It should be noted, however, that the variations in the lower subunit (yellowish diamicton), which can be seen in the cliff at Babie Doły, do not indicate a record that is concordant with ice flow. The cliff face is almost perpendicular to the orientation of the resultant vector of the clast fabric in the lower subunit. In this case we should rather speak of a record of parallel development of different conditions in the ice bed over a small space, which confirms the concept of mosaic nature in areas of the soft bed of the ice sheet (compare Piotrowski et al., 2004; Evans et al., 2006).

Undoubtedly, one of the most interesting issues to consider on the basis of results presented here is the record of the reactivation of ice sheet motion, combined with a change in direction of the ice flow. This is marked by the upper subunit of the basal till (pink diamicton). Although it does not display such distinct features of active ice deposition as the lower subunit (they might have been obliterated as a result of intensive shearing), its other features should be considered indicative. The first one is the erosive-deformational contact with the lower subunit (smudges of yellowish diamicton in the bottom section of pink diamicton; Fig. 3J). The second piece of evidence are clasts whose bottom parts protrude from the basal part of the pink diamicton and are stuck in the top of the yellowish diamicton (which indicates ploughing; Fig. 3M). What should be considered extremely important are changes in till fabric and petrographic composition. The lower subunit was deposited by the ice sheet that transported debris from the north; in the upper one debris inflow from the northwest was very clear (compare Figs. $4 \mathrm{~A}$ and $4 \mathrm{~B}$ ). The change of rock source zones is confirmed by the TBC location for both subunits (Fig. 5). The TBC of the upper subunit is skewed to the southwest with respect to the TBC calculated for the lower subunit. A similar situation has previously been documented at Kartoszyno, located further to the west of the Gulf of Gdańsk (Woźniak et al., 2009). This change of petrographic composition is consistent with the observed changes in the till fabric in sections at Babie Doły (Fig. 2). The directional properties at the bottom of the bed document the flow of ice masses from the northeast. In the upper part of the till unit there is a notable change in till fabric - the NNW sector predominates. This is similar to the situation at Kartoszyno. The change in the debris source area recorded at Babie Doły and Kartoszyno was in the opposite direction to that observed at sites along the southern edge of the Gulf of Gdańsk and further south, in the area along the northern part of the Lower Vistula Valley (Fig. 5), where ice flow direction was quite stable through- out the entire stadial, with reference to the course of the axis of the depression of the Gulf of Gdańsk and the palaeo-Vistula valley (Woźniak \& Czubla, 2015).

When comparing the composition of assemblages of indicator erratics in these subunits, a very clear change in debris source area is observed. This is expressed by a decrease in importance of rocks from central Fennoscandia (Dalarna, Åland region, Uppland, Stockholm area) in favour of those from southern Sweden and Bornholm in the upper subunit (Fig. 4). The change of supply area, documented by petrographic studies at Babie Doły and Kartoszyno, contrasts with the trend described by Ehlers (1981, 1983; see also Ehlers \& Stephan, 1983), despite the fact that the results from sites along the southern edge of the Gulf of Gdańsk and further south (compare Figs. 1A and 5) support this trend. According to Ehlers, during early development of each glaciation, the ice divide was near the main Scandinavian drainage divide. With the areal development of the ice sheet it gradually moved east as far as the coastal zone of the contemporary Bothnian Bay. A similar conclusion was drawn from interpretations of ice sheet inflow directions in Estonia, where it was assumed that the centre of glaciation moved progressively from the Scandinavian Mountains eastwards to central Finland, determining the meridional flow of ice into the area of present-day Estonia (Tavast \& Raukas, 1982; Raukas, 1995). In the final period of glaciation, when climate change led to progressive reduction of ice sheet extent, it is assumed that the divide line shifted back to its original position in the Scandinavian Mountains (Ehlers, 1981, 1983). Thus, the till section at Babie Doły might represent this declining stage. Ehlers's concept did not consider the ice stream character of the Fennoscandian Ice Sheet (compare Punkari, 1993, 1997). In areas of potential activity of ice streams (surely including the region of the Gulf of Gdańsk), ice sheet dynamics, however, could have been characterised by a very high temporal and spatial variability. This is expressed as a large variation of directions from which the ice flowed, recognised at sites along the north-western vicinity of the Gulf of Gdańsk (compare Woźniak et al., 2009; Woźniak \& Czubla, 2015).

The origin of rocks of local provenance in the till is also an important issue. The lower till subunit contains at least $10-15 \%$ of them. These are mainly Mesozoic carbonate, clastic and siliceous rocks, mostly Upper Cretaceous, perhaps also include lower Palaeogene. In the vicinity of the study site Upper Cretaceous rocks directly underlying the Quaternary cover are found at the bottom of the Gulf of Gdańsk (compare Asch, 2005). The di- 
rectional characteristics of the lower part of the till unit document the flow of ice masses from the northeast, which confirms the origin of rocks of local provenance from that area. In the upper subunit, which developed as a result of ice inflow from a north-north-westerly direction, the percentage of rocks of local provenance is small. This is due to the fact that in the area north and northwest of Babie Doły Quaternary deposits are isolated from the Cretaceous and Paleogene substrate by soft and/ or fine-grained Miocene and Pliocene sediments (Leszczyński, 2012). The Quaternary sediments, including the older glacial deposits, might have furnished additional protection, as documented by several authors (e.g., Kjær et al., 2003; Czubla, 2006; Czubla et al., 2010, 2013). In our view, the content of Neogene rocks in the fine gravel fraction $(5-10 \mathrm{~mm})$ of the upper subunit is negligible for other reasons. These rocks are very loose, easily undergoing comminution during ice transport; in such a situation they transform into a finer fraction, in which they are not recognisable. This results in a very low content of rocks of local provenance in the fine gravel fraction of the till. Similar conclusions can be drawn on the basis of the results of studies of the $>20 \mathrm{~mm}$ fraction. In the lower subunit of the till at Babie Doły rocks of local provenance constitute approximately $4 \%$ of clasts, while they are completely absent in the upper subunit. Perhaps the enrichment of the matrix with material from the comminution of non-resistant rocks is responsible for the specific pink colour of the upper subunit. It is most likely that originally these could have been Triassic brickred claystones and fine-grained sands, outcrops of which are found to the northwest of the area in question (including Skompski, 1985) - along the route of the inflowing ice.

The upper Weichselian till (subunits B3a and $\mathrm{B} 3 \mathrm{~b})$ described represents the entire stadial. The complexity of its profile is the effect of changes in ice sheet dynamics throughout this period, without the freeing the analysed area from under the ice cover. Features of the lower subunit indicate that it was formed by the ice, the motion of which was significantly conditioned by the base slip. This is supported by, amongst other data, evidence of ice-bed decoupling and of subglacial flows and the limited thickness of the deformation layer in sediments underlying the till. The lower subunit can be associated with the impact of the Vistula palaeo-ice stream (compare Boulton et al., 2001; Narloch et al., 2012, 2013). The upper subunit was deposited probably by ice that was not associated with this palaeo-ice stream; the ice advanced from a different direction and probably more slowly. This is supported mainly by a lack of geomorphological evidence of fast ice advance (both in the study area, and at its northwesterly foreland, from where the potential palaeo-ice stream would have advanced) as well as topographic conditions adverse to ice streams formation. The only evidence of ice movement acceleration in the top subunit (ploughed clasts) is found in its basal part. They may suggest fast ice movement during the initial stage of activation following a stagnation period. Higher no traces of fast ice movement have been found. Such conclusions are supported by results of petrographic research. The places where the entire till section developed as a result of ice inflow along the axis of the Gulf of Gdańsk and the Lower Vistula Valley region (Fig. 1A), i.e., in the zone of the potential Vistula palaeo-ice stream, the TBC of the upper subunit is slightly shifted towards the east in relation to the lower subunit (see Fig. 5; compare Woźniak \& Czubla, 2015). This means that the source area of erratics shifted only slightly to the east and remained in the onset zone of the Vistula palaeo-ice stream. At sites located along the northwesterly edge of the Gulf of Gdańsk (Babie Doły and Kartoszyno) there is a clear shift in source area of erratics (compare Woźniak et al., 2009). The TBC location of the upper subunit is shifted towards the southwest in relation to the lower one. This points to the intake of the debris deposited in the upper part of the till profile was outside the potential erratics source area of the Vistula palaeo-ice stream.

Unambiguous correlation of the two subunits to specific glacial phases is impossible. However, based on studies of the $>20 \mathrm{~mm}$ fraction at other sites in the vicinity of the Gulf of Gdańsk and to the south of it (Woźniak \& Czubla, 2015) it can be assumed that the lower subunit, which is characterised by a very high content of Åland and Dalarna rocks, corresponds to the Leszno/Brandenburg Phase, while the upper one, which contains a significant contribution of rocks from southeast and southern Sweden, represents the non-separated Poznań/Frankfurt and Pomeranian phases.

At the end we need to come back to the question of decalcification of the basal part of the till at Babie Doły. The discussed till builds only upper part of the investigated cliff section. Below are primarily permeable sands of considerable thickness. In this situation, the impact of the contemporary groundwater on the basal part of the till can be excluded. The $\mathrm{CaCO}_{3}$ content in the till matrix is low, not only in the basal part of the till found in the contemporary exposed cliff face, but within it as well $(0.5 \mathrm{~m}$ within the till, $\mathrm{CaCO}_{3}$ content in matrix is $\left.<1 \%\right)$. We assume that the decalcification of the basal part of 
the till is the effect of groundwater processes that took place prior to the moment the cliff section reached its recent position. Primary decalcification may have been hampered contemporarily by contact of the till with moisture derived from the colluvium at the cliff face, which covers the basal part of the till. The long retention of colluvium at Babie Doły is due mainly to the fact that the cliff retreats very slowly, because its base is protected by a concrete breakwater (Fig. 1C).

\section{Conclusions}

The Babie Doły site documents a glacial sequence whose complexity stems from its multi-stage origin. The sedimentary succession (from the base): basal till - glaciofluvial and paralimnic sediments - clast-supported diamicton of gravity flows, documents successive stages of deposition, associated with development of the ice sheet in the study area, and then decay of the ice cover. The basal till represents almost the entire Upper Weichselian and reveals a record of changing directions of inflow of ice masses and debris supply. What is observed is a considerable horizontal variation in the characteristics of facies, showing the synchronous occurrence of different conditions in the ice sheet bed over a small area, which confirms the concept of the mosaic nature of subglacial sedimentation in the areas of the ice sheet soft bed. In the basal till, the dichotomy of the profile is clearly marked, which is due to the changing impact of the ice masses:

- the lower subunit (B3a) formed by the advance of the palaeo-ice stream along the main axis of the Baltic Sea (from the north), expanding to areas adjacent of the depression of the Gulf of Gdańsk (hence a till fabric showing a northeasterly direction),

- the upper subunit (B3b) formed when the impact of the palaeo-ice stream diminished in the study area, and the main role was assumed by ice flow from the northwest.

The change in debris source area (between these stages) was in the opposite direction to that observed at sites along the southern edge of the Gulf of Gdańsk and further south, in the area along the northern part of the Lower Vistula Valley, where the direction of the ice flow throughout the entire stadial was quite stable, referring to the course of axis of the depression of the Gulf of Gdańsk and the palaeo-Vistula valley.

The upper part of the sedimentary succession (overlying the basal till) formed after the area was freed from the continuous ice cover, but in the vi- cinity of dead ice that was subjected to intense ablation. The first local washing of the till top occurred and the resultants were as follows:

- sandy, sandy-silty and silty sediments of glaciofluvial and paralimnic deposition (unit B4),

- the upper diamicton layer - clast-supported diamicton redeposited from dead ice by gravity flows (unit B5).

\section{Acknowledgements}

We express thanks to Stanisław Fedorowicz for TL dating, and to Anna Kąkol and Artur Wolniewicz for assistance in both field work and sample preparations. We are grateful to Aleksandra Zaparucha for linguistic support. The valuable comments of Włodzimierz Narloch and an anonymous reviewer have been of great help in improving an earlier version of the typescript. This work has been financially supported by the National Science Centre on the basis of project no. N N306 766940.

\section{References}

Alley, R.B., 1989. Water pressure coupling of sliding and bed deformation: II. Velocity-depth profiles. Journal of Glaciology 35, 119-129.

Asch, K., 2005. IGME 5000: 1 : 5 Million International Geological Map of Europe and Adjacent Areas - final version for the internet. BGR, Hannover.

Benn, D.I., 1994, Fabric shape and the interpretation of sedimentary fabric data. Journal of Sedimentary Research A64, 910-915.

Bennett, M.R. \& Glasser N.F., 2009. Glacial geology: ice sheets and landforms. John Wiley \& Sons, Chichester, 385 pp.

Bennett, M.R., Waller, R.I., Glasser, N.F., Hambrey, M.J. \& Huddart, D., 1999. Glacigenic clast fabric: genetic fingerprint or wishful thinking? Journal of Quaternary Science 14, 125-135.

Boulton, G.S., 1977. A multiple till sequence formed by a late Devensian Welsh ice cap: Glanllynnau, Gwynedd. Cambria 4, 10-31.

Boulton, G.S., Dongelmans, P., Punkari, M. \& Broadgate, M., 2001. Palaeoglaciology of an ice sheet through a glacial cycle: the European ice sheet through the Weichselian. Quaternary Science Reviews 20, 591-625.

Brodzikowski, K. \& van Loon, A.J., 1991. Glacigenic sediments. Elsevier, Amsterdam, 674 pp.

Carr, S.J. \& Rose, J., 2003. Till fabric patterns and significance: particle response to subglacial stress. Quaternary Science Reviews 22, 1415-1426.

Clark, P.U. \& Hansel, A.K., 1989. Clast ploughing, lodgement and glacier sliding over a soft glacier bed. Boreas 18, 201-207.

Czubla, P., 2001. Eratyki fennoskandzkie w utworach czwartorzędowych Polski Środkowej i ich znaczenie stratygraficzne [Fennoscandian Erratics in Quaternary Deposits of Middle Poland and their Value for 
Stratigraphic Purposes]. Acta Geographica Lodziensia 80, 174 pp. [in Polish with English summary].

Czubla, P., 2006. The stratigraphic significance of Indicator Erratics Counts from Glacial Deposits - An Example from Eastern Wielkopolska (Great Poland Lowland). Archiv für Geschiebekunde 5, 177-190.

Czubla, P., Forysiak, J. \& Petera-Zganiacz, J., 2010. Lithological and petrographic features of tills in the Koźmin region and their value for stratigraphical interpretation of glacial Lake Koźmin deposits, Central Poland. Geologija 52, 1-8.

Czubla, P., Forysiak, J., Petera-Zganiacz, J., Grajoszek, M. \& Wiśniewska, M., 2013. Charakterystyka litologiczno-petrograficzna osadów czwartorzędowych w dolinie Warty (stanowisko Koźmin Północ) [The lithological and petrographic features of the Quaternary deposits in theWarta River valley (Koźmin-North site)]. Przeglad Geologiczny 61, 120-126 [in Polish with English summary].

Dreimanis, A., 1962. Quantitative gasometric determination of calcite and dolomite by using Chittick apparatus. Journal of Sedimentary Petrology 32, 520-529.

Ehlers, J., 1981. Problems of the Saalian Stratigraphy in the Hamburg area. Mededelingen - Rijks Geologische Dienst 34, 26-29.

Ehlers, J., 1983. Different till types in North Germany and their origin. [In:] E.B. Evenson, Ch. Schlüchter \& J. Rabassa (Eds), Tills and related deposits. Balkema, Rotterdam, 61-80.

Ehlers, J., Stephan, H.J., 1983. Till fabric and ice movement. [In:] J. Ehlers (Ed.) Glacial deposits in North-West Europe. Balkema, Rotterdam, 267-274.

Evans, D.J.A., Phillips, E.R., Hiemstra, J.F. \& Auton, C.A., 2006. Subglacial till: formation, sedimentary characteristics and classification. Earth Science Reviews 78, 115-176.

Eyles, N., Eyles, C.H. \& Miall, A.D., 1983. Lithofacies types and vertical profile models; an alternative approach to the description and environmental interpretation of glacial diamict and diamictite sequences. Sedimentology 30, 393-410.

Fedorowicz, S., Łanczont, M., Bogucki, A., Kusiak, J., Mroczek, P., Adamiec, G., Bluszcz, A., Moska, P. \& Tracz, M., 2013. Loess-paleosol sequence at Korshiv (Ukraine) - chronology based on complementary and parallel dating (TL, OSL), and litho-pedosedimentary analyses. Quaternary International 296, 117-130.

Hart, J.K., Rose, K.C, Martinez, K. \& Ong, R., 2009. Subglacial clast behaviour and its implication for till fabric development: new results derived from wireless subglacial probe experiments. Quaternary Science Reviews 28, 597-607.

Jørgensen, F. \& Piotrowski, J.A., 2003. Signature of the Baltic Ice Stream on Funen Island, Denmark during the Weichselian glaciation. Boreas 32, 242-255.

Kjær, K.H., Houmark-Nielsen, M. \& Richardt, N., 2003. Ice-flow patterns and dispersal of erratics at the southwestern margin of the last Scandinavian Ice Sheet: signature of palaeo-ice streams. Boreas 32, 130-148.

Koutaniemi, L. \& Rachocki, A.H., 1987. Origin of pradolinas. Zeitschrift für Gletscherkunde und Glazialgeologie 23, 65-76.
Kozarski, S., 1988. Origin of pradolinas: a discussion of mistaken ideas. Zeitschrift für Gletscherkunde und Glazialgeologie 24, 75-92.

Lagerlund, E., Malmberg-Persson, K., Krzyszkowski, D., Johansson, P., Dobracka, E., Dobracki, R. \& Panzig, W.A., 1995. Unexpected ice flow directions during the late Weichselian deglaciation of the south Baltic area indicated by a new litostratigraphy in NW Poland and NE Germany. Quaternary International 28, 127-144.

Larsen, N.K. \& Piotrowski, J.A., 2003. Fabric pattern in a basal till succession and its significance for reconstructing subglacial processes. Journal of Sedimentary Research 73, 725-734.

Leszczyński, K., 2012. The internal geometry and lithofacies pattern of the Upper Cretaceous-Danian sequence in the Polish Lowlands. Geological Quarterly $56,363-386$.

Lüttig, G., 1958. Methodische Fragen der Geschiebeforschung. Geologisches Jahrbuch 75, 361-417.

Mark, D.M., 1973. Analysis of axial orientation data, including till fabrics. Geological Society of America Bulletin 84, 1369-1374.

Marks, L., 2012. Timing of the Late Vistulian (Weichselian) glacial phases in Poland. Quaternary Science Reviews 44, 81-88.

Miall, A.D., 1978. Lithofacies types and vertical profile models in braided rivers: a summary. [In:] A.D. Miall (Ed.), Fluvial Sedimentology. Canadian Society of Petroleum Geology Memoir 5, 597-604.

Mojski, J. E., 1979. Objaśnienia do szczegótowej mapy geologicznej Polski, arkusz Gdynia [Explanations to the Detailed Geological Map of Poland, sheet Gdynia]. Wydawnictwa Geologiczne, 40 pp. [in Polish].

Narloch, W., Wysota, W. \& Piotrowski, J.A., 2013. Sedimentological record of subglacial conditions and ice sheet dynamics of the Vistula Ice Stream (north-central Poland) during the Last Glaciation. Sedimentary Geology 293, 30-44.

Narloch, W., Piotrowski, J.A., Wysota, W., Larsen, N.K. \& Menzies, J., 2012. The signature of strain magnitude in tills associated with the Vistula Ice Stream of the Scandinavian Ice Sheet, central Poland. Quaternary Science Reviews 57, 105-120.

Paterson, W.S.B., 1994. The physics of glaciers. 3rd ed. Pergamon, Oxford, 481pp.

Pazdro, Z., 1960. Budowa geologiczna regionu gdańskiego [Geology of the Gdańsk region]. Rocznik Polskiego Towarzystwa Geologicznego 29, 337-346 [in Polish].

Pikies, R. \& Zaleszkiewicz, L., 2003. Objaśnienia do szczegótowej mapy geologicznej Polski, arkusz Rumia [Explanations to the Detailed Geological Map of Poland, sheet Rumia]. Państwowy Instytut Geologiczny, 42 pp. [in Polish].

Piotrowski, J.A. \& Kraus, A.M., 1997. Response of sediment to ice sheet loading in northwestern Germany: effective stresses and glacierbed stability. Journal of Glaciology 43, 495-502.

Piotrowski, J.A. \& Tulaczyk, S., 1999. Subglacial conditions under the last ice sheet in northwest Germany: ice-bed separation and enhanced basal sliding? Quaternary Science Reviews 18, 737-751. 
Piotrowski, J.A., Hermanowski, P. \& Piechota, A.M., 2009. Meltwater discharge through the subglacial bed and its land-forming consequences from numerical experiments in the Polish lowland during the last glaciation. Earth Surface Processes and Landforms 34, 481-492.

Piotrowski, J.A., Larsen, N.J. \& Junge, F.W., 2004. Reflections on soft subglacial beds as a mosaic of deforming and stable spots. Quaternary Science Reviews 23, 993-1000.

Piotrowski, J.A., Larsen, N.K., Menzies J., \& Wysota, W., 2006. Formation and subglacial till under transient bed conditions: deposition, deformation, and basal decoupling under Weichselian ice sheet lobe, central Poland. Sedimentology 53, 83-106.

Punkari, M., 1993. Modelling of the dynamics of the Scandinavian ice sheet using remote sensing and GIS methods. [In:] J.S. Aber (Ed.), Glaciotectonics and Mapping Glacial Deposits. Proceedings of the INQUA Commission on Formation and Properties of Glacial Deposits. Regina, 232-250.

Punkari, M., 1997. Glacial and glaciofluvial deposits in the interlobate areas of the Scandinavian Ice Sheet. Quaternary Science Reviews 16, 741-753.

Rachocki, A.H. \& Koutaniemi, L., 1992. The origin of pradolinas: a reassesment. A reply to S. Kozarski. Zeitschrift für Gletscherkunde und Glazialgeologie 27/28, 37-50.

Raukas, A., 1995. Estonia - a land of big boulders and rafts. Questiones Geographicae, Special Issue 4, 247-253.

Rzechowski, J., 1971. Granulometryczno-petrograficzne własności glin zwałowych w dorzeczu środkowej Widawki [Granulometric-petrographic properties of the tills in the drainage basin of the middle Widawka]. Biuletyn Instytutu Geologicznego 254, 111-155 [in Polish with English summary].

Salamon, T., 2014. Basal till and subglacial conditions at the base of the Upper Odra Lobe (southern Poland) during the Odranian Glaciation. Geological Quarterly $58,4,779-794$.

Shaw, J., 1982. Melt out till in the Edmonton area, Alberta, Canada. Canadian Journal of Earth Sciences 19, 1548-1569.

Skompski, S., 1985. Objaśnienia do szczegółowej mapy geologicznej Polski, arkusz Choczewo [Explanations to the Detailed Geological Map of Poland, sheet Choczewo]. Wydawnictwa Geologiczne, Warszawa, 80 pp. [in Polish].

Smed, P., 1993. Indicator studies: a critical review and a new data-presentation method. Bulletin of the Geological Society of Denmark 40, 332-344.

Subotowicz, W., 1982. Litodynamika brzegów klifowych wybrzeża Polski [The lithodynamic of cliff sections at the Pol- ish Baltic sea coast]. Ossolineum, Wrocław, 150 pp. [in Polish with German summary].

Tavast, E. \& Raukas, A., 1982. Relief koriennykh porod Estonii [The bedrock relief of Estonia]. Valgus, Tallinn, 192 pp. [in Russian with English summary].

Trembaczowski, J., 1961. Przyczynki do metodyki badań granulometryczno-petrograficznych utworów morenowych [Contributions to the methods of investigation of the grain-size and petrography of morainic deposits]. Annales Universitatis Maria Curie-Skłodowska, Sectio B 16, 63-94 [in Polish with English summary].

Trommelen, M. S. \& Ross, M. 2014. Distribution and type of sticky spots at the centre of a deglacial streamlined lobe in northeastern Manitoba, Canada. Boreas 43, 557-576.

Trommelen, M.S., Ross, M. \& Campbell, J.E., 2013. Inherited clast dispersal patterns: Implications for palaeoglaciology of the SE Keewatin Sector of the Laurentide Ice Sheet. Boreas 42, 693-713.

Tylmann, K., Piotrowski, J. A. \& Wysota, W. 2013. The ice/bed interface mosaic: deforming spots intervening with stable areas under the fringe of the Scandinavian Ice Sheet at Sampława, Poland. Boreas 42, 428-441.

Vinx, R., Grube, A. \& Grube, F., 1997. Vergleichende Lithologie, Geschiebeführung und Geochemie eines Prä-Elster-I-Tills von Lieth bei Elmshorn. Leipziger Geowissenschaften 5, 83-103.

Wintle, A.G. \& Prószyńska, H., 1983. TL Dating of loess in Germany and Poland. PACT 9, 547-554.

Woźniak, P.P., 2006. Interpretational problems induced by regional changeability of petrographic till composition. Archiv für Geschiebekunde 5, 237-250.

Woźniak, P.P. \& Czubla, P., 2015. The Late Weichselian glacial record in northern Poland: A new look at debris transport routes by the Fennoscandian Ice Sheet. Quaternary International 386, 3-17.

Woźniak, P.P., Czubla P., Wysiecka G. \& Drapella M., 2009. Petrographic composition and directional properties of tills on the NW surroundings of Gdańsk Bay, Northern Poland. Geologija 51, 59-67.

Wysota, W., 2007. Successive subglacial depositional processes as interpreted from basal till in the Lower Vistula valley (N Poland). Sedimentary Geology 193, 21-31.

Wysota, W., Molewski, P. \& Sokołowski, R., 2009. Record of the Vistula ice lobe advances in the Late Weichselian glacial sequence in north-central Poland. Quaternary International 207, 26-41.

Manuscript submitted 15 September 2015 Revision accepted 11 January 2016 